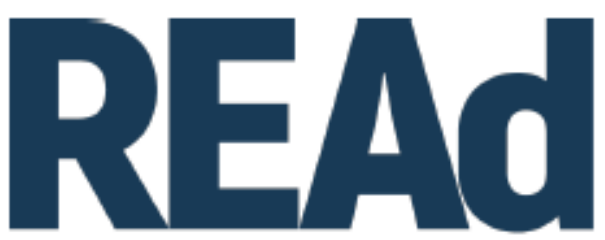

Revista Eletrônica de Administração

\title{
ANÁLISE ERGOLÓGICA DA TRAJETÓRIA DE VIDA DE UM SINDICALISTA ${ }^{1}$
}

\author{
Kleyton Teixeira Valadão ${ }^{2}$ \\ Mônica de Fátima Bianco ${ }^{3}$
}

http://dx.doi.org/10.1590/1413-2311.321.105248

\section{RESUMO}

Desde os anos 1990 no Brasil, estudiosos revelam haver uma escalada contra os direitos trabalhistas, submetendo os trabalhadores a diferentes formas de precarização. Tais acontecimentos favoreceram a emergência de um sindicalismo neoliberal e, também, a inflexão de Centrais sindicais, às vezes falhando em propor alternativas contrárias ao padrão de desenvolvimento capitalista. $\mathrm{O}$ foco desta pesquisa está na atividade do sindicalista, diretor de um sindicato de vigilância privada, e foi adotado o método história de vida. $\mathrm{O}$ artigo tem por objetivo compreender as experiências vividas pelo sindicalista entrevistado e os usos do corposi em sua atividade de trabalho. $\mathrm{O}$ uso da Ergologia teve o intuito de incitar aqueles que vivem e trabalham a pôr em palavras um ponto de vista sobre a sua atividade. A história de vida de Juvenal evidencia os debates de normas e valores, usos do corpo-si, os tensionamentos entre as três esferas, 1) sindicalismo, 2) mercado e 3) Estado. A história de vida pôde convocar o trabalhador para produzir saberes sobre sua própria existência, inclusive em seu trabalho, além de dar voz a certos grupos socialmente invisíveis. A história de Juvenal representa as histórias de vida de outros brasileiros que lutam pelo direito de viver tendo trabalho digno.

Palavras-Chave: Sindicalismo. Ergologia. História de Vida. Trabalho. Estudos Organizacionais.

\section{ERGOLOGICAL ANALYSIS OF A SYNDICALIST'S LIFE PATH}

Since the 1990s in Brazil, scholars have revealed an escalation against labor rights, subjecting workers to different forms of insecurity. Such events favored the emergence of liberal unionism and, also, the inflection of union centrals, sometimes failing to propose alternatives contrary to

\footnotetext{
${ }^{1}$ Recebido em 9/7/2020, aceito em 10/5/2021.

${ }^{2}$ Universidade Federal do Espírito Santo - Programa de Pós-Graduação em Administração; Vitória (ES), Brasil; http://orcid.org/0000-0001-5327-867X; kleytonvaladao@hotmail.com.

${ }^{3}$ Universidade Federal do Espírito Santo - Programa de Pós-Graduação em Administração; Vitória (ES), Brasil; http://orcid.org/0000-0003-4280-7630; mofbianco@ gmail.com.
} 
the pattern of capitalist development. The focus of this research is on the activity of the union leader, director of a private surveillance union, and the life history method was adopted. The article aims to understand the experiences of the union member interviewed and the uses of the self-body in his work activity. The use of Ergology was intended to incite those who live and work to put into words a point of view about their activity. Juvenal's life story highlights the debates on norms and values, uses of the self-body, the tension between the three spheres, 1) unionism, 2) the market and 3) the state. The life story was able to summon the worker to produce knowledge about his own existence, including in his work, in addition to giving voice to certain socially invisible groups. Juvenal's story represents the life stories of other Brazilians who fight for the right to live with decent work.

Keywords: Unionism. Ergology. Life's history. Job. Organizational Studies.

\section{ANÁLISIS ERGOLÓGICO DE LA TRAYECTORIA DE VIDA DE UN UNIONISTA}

Desde la década de 1990 en Brasil, los académicos han revelado una escalada de los derechos laborales, sometiendo a los trabajadores a diferentes formas de inseguridad. Tales hechos favorecieron el surgimiento del sindicalismo neoliberal y, también, la inflexión de centrales sindicales, fallando en ocasiones en proponer alternativas contrarias al patrón de desarrollo capitalista. El enfoque de esta investigación está en la actividad del líder sindical, director de un sindicato de vigilancia privado, y se adoptó el método de historia de vida. El artículo tiene como objetivo comprender las experiencias del sindicalista entrevistado y los usos del cuerposi en su actividad laboral. El uso de la Ergología tenía como objetivo incitar a quienes viven y trabajan a expresar con palabras un punto de vista sobre su actividad. La historia de vida de Juvenal destaca los debates sobre normas y valores, usos del cuerpo-si, la tensión entre las tres esferas, 1) sindicalismo, 2) el mercado y 3) el estado. La historia de vida supo convocar al trabajador a producir conocimiento sobre su propia existencia, incluso en su obra, además de dar voz a ciertos grupos socialmente invisibles. La historia de Juvenal representa las historias de vida de otros brasileños que luchan por el derecho a vivir con un trabajo digno.

Palabras clave: Sindicalismo. Ergología. Historia de Vida. Trabajo. Estudios Organizacionales.

\section{INTRODUÇÃO}

Como resultado da concorrência intercapitalista, bem como da necessidade de controlar o movimento operário e a luta de classes, as transformações no processo de produção acabam levando à fragmentação, heterogeneização e complexificação da classe trabalhadora, desafiando seus organismos de representação, especialmente os sindicatos, a buscarem estratégias de luta que contemplem a totalidade dos trabalhadores, profundamente atingidos pelo desemprego estrutural e pela "subproletarização" ou precarização do trabalho, decorrentes 
da expansão do trabalho parcial, temporário, subcontratado e terceirizado (CAVAIGNAC, 2012).

As novas formas de contratação impostas pela reestruturação produtiva, em resposta à crise do capital, têm um conteúdo não apenas econômico, no sentido de reduzir custos e aumentar a lucratividade, mas também um forte conteúdo político, fragmentando a classe trabalhadora e fragilizando a capacidade organizativa dos sindicatos, que haviam conquistado um forte poder de pressão nos anos 1970 e início dos anos 1980, período de aprofundamento da crise do regime militar, marcado pelo crescimento da oposição política e pela ascensão de organizações trabalhistas, principalmente com o surgimento do Partido dos Trabalhadores (PT), em 1980; a criação da Central Única dos Trabalhadores (CUT), em 1983; a fundação do Movimento Nacional dos Trabalhadores Rurais Sem-Terra (MST), em 1985 e a gênese da Força Sindical em 1991. Nesse período, o movimento sindical caracterizou-se por um conjunto de práticas sociais que, dialogando criticamente com práticas anteriores (o "velho sindicalismo") e buscando superar as limitações e os erros dos que vieram antes, ficou conhecido como "Novo Sindicalismo" (CAVAIGNAC, 2012).

Já o contexto econômico e político na década de 1990 impôs ao movimento sindical os desafios decorrentes além das estratégias gerenciais, como as inovações técnicas, e a crise fiscal dos estados, cujas consequências sobre o mercado de trabalho têm sido bastante negativas. O poder sindical foi atingido pelos impactos sobre a ação coletiva provocados pela redução do emprego assalariado, evidenciada tanto pelo aumento de desempregados quanto pela proliferação de formas alternativas de trabalho, sobretudo no setor informal. As mudanças estruturais em âmbito macro e microeconômico verificadas na sociedade brasileira afetaram o movimento sindical (COLBARI, 2003).

No campo da gestão, diversas decisões tomadas pelos gestores não são seguidas dos efeitos esperados e uma das razões fundamentais desses fracassos se deve do fato de que os gestores que estavam na base dessas decisões se esqueceram das dimensões centrais do comportamento humano, consequência do déficit de estudos de disciplinas que se interessam pela ação humana, como as ciências sociais (CHANLAT, 2011). Um dedicado estudo dessa área do conhecimento permitiria com que eles compreendessem melhor o que ocorre, e, daí, refletissem melhor sobre o que é preciso fazer a partir do conhecimento obtido de suas práticas.

Fundamentaria assim uma gestão compreensiva e reflexiva, que busca, ainda que seja uma tarefa difícil, o equilíbrio entre a dinâmica social e as exigências econômicas, 
contemplando tanto as organizações como os indivíduos que nelas trabalham. Isso porque o gestor, enquanto ator social, é simultaneamente sujeito e objeto das intervenções em seu meio, ele tem uma margem de manobra dentro do que ele pode fazer e na maneira como ele pode reagir ao que os outros lhe fazem. Ele também é sujeito em atos, portador de uma identidade profissional, um trabalhador em situação, enraizado em um espaço-tempo, em busca de significado e cuja ação é orientada por valores (SCHWARTZ, 2010d; CHANLAT, 2011).

No que tange ao trabalho como objeto de pesquisa nos Estudos Organizacionais, temse buscado dialogar não só com as ciências sociais, mas como outras áreas do conhecimento, como a Psicologia, a Medicina, a Filosofia, etc. (DEJOURS, 1987; DEJOURS et al., 1993; WISNER, 1994; CANGUILHEM, 2000; CLOT, 2006; ODDONE, 2007; CHANLAT, 2011). Essa pluridisciplinaridade abre caminho para romper com a corrente gerencial clássica da Administração.

Neste sentido, surgiu a oportunidade do estudo do trabalho a partir da abordagem ergológica como um projeto de melhor conhecer, e, sobretudo, de melhor intervir sobre as situações de trabalho para transformá-las (SCHWARTZ, 2010d). Schwartz (2003) alerta sobre os modelos teóricos que subestimam ou anulam os aspectos subjetivos do ser humano, como os saberes da experiência e o debate de valores. Para o autor, as pesquisas que modelizam o indivíduo são falta de humildade do pesquisador e uma forma de enfraquecer a concepção histórica e complexa do indivíduo.

Assim, no atual contexto de precarização do trabalho e da atividade sindical brasileira, se faz necessário o olhar e o estudo da academia sobre o fenômeno, visto que os sindicatos, por sua vez, representam um importante instrumento de luta por direitos, seja por melhores condições de trabalho e vida, seja pelo elo de identidade que firmam entre o sujeito trabalhador e sua classe.

Como aqui parte-se do princípio de que o trabalho é a realização dos homens (SCHWARTZ, 2011), que a abordagem ergológica permite empoderamento dos trabalhadores (TRINQUET, 2010; DURRIVE, 2011; SCHWARTZ, 2014), que o método de história oral de vida dá voz, reflexão e consciência social aos sujeitos (ALBERTI, 2004; BARROS; LOPES, 2014) e a luta pelo trabalho digno passa pela atuação firme dos sindicatos (ANTUNES, 1998, 2002), desenha-se então um cenário ideal para os propósitos desta pesquisa, pois tal investigação vai expor fenômenos significativos nas experiências vividas pelos sindicalistas em suas situações de trabalho. 
Quer-se investigar como a Ergologia — principalmente, com base no conceito de uso do corpo-si — poderia contribuir para entender a complexidade das situações de trabalho enfrentadas pelo sindicalista atuante no Sindicato dos empregados nas empresas de transporte de valores, escolta armada, ronda motorizada, monitoramento eletrônico e via satélite, agente de segurança pessoal e patrimonial, segurança e vigilância em geral e as trocas de poder existentes na interação sindicato-mercado-Estado com base na Economia Política do Poder de Faria (2002). Não foi encontrado, todavia, nenhum trabalho acadêmico que utilize a Ergologia junto com a História oral de vida na pesquisa sobre o trabalho sindical.

$\mathrm{O}$ interesse em realizar este trabalho decorreu do contexto político-econômico e histórico do Brasil nos anos de 2017, 2018 e 2019, um momento de radicalização políticoideológica, que atinge de forma significativa as relações de trabalho, como a precarização dos postos de trabalho, a informalidade, a perda de direitos trabalhistas e previdenciários, a terceirização, o desemprego e o desmonte dos sindicatos. Como o neoliberalismo ataca o valor do trabalho, a coletividade e o princípio de solidariedade, os sindicatos se configuram como peças fundamentais para zelar por melhores condições de trabalho e de vida, além de garantir o exercício democrático inserindo a classe trabalhadora nos centros de poder. Compreender como se desenvolve a luta sindical é imprescindível para a manutenção do Estado Democrático de Direito, e esta pesquisa buscou dar voz a um sindicalista de modo aprofundado, exatamente para relembrar à sociedade que é o trabalho que a transforma, e que o trabalho é realizado por pessoas, que vivem e que sofrem, cada um com suas experiências e particularidades. Configurase então a seguinte questão: o que a história de vida de um sindicalista pode revelar, pela perspectiva ergológica, sobre o sindicalismo?

Assim o objetivo geral desta pesquisa é, com base em relatos, compreender as experiências vividas pelo sindicalista entrevistado e os usos do corpo-si em sua atividade de trabalho. A seguir, um breve referencial teórico foi elaborado para introduzir o assunto.

\section{A LUTA SINDICAL NO BRASIL A PARTIR DOS ANOS 1980}

O sindicalismo brasileiro presenciou na década de 1980 um momento particularmente positivo. Houve uma significativa expansão do sindicalismo dos assalariados médios e do setor de serviços; continuou-se o desenvolvimento do sindicalismo rural; nasceram as centrais sindicais; efetivou-se um avanço na luta pela autonomia e liberdade dos sindicatos em relação 
ao Estado; verificou-se um aumento do número de sindicatos, dentre eles se destaca a presença de funcionários públicos; e, acompanhando esse processo, aumentaram-se as taxas de sindicalização (ANTUNES, 2002).

Porém, ainda no final da década de 1980, acentuavam-se tendências ideológicas, políticas e econômicas que determinaram a regressão desse novo sindicalismo. As propostas de desregulamentação, de flexibilização, de privatização e de desindustrialização tiveram nesses anos forte influência no Brasil. Tais acontecimentos favoreceram de um lado a emergência de um sindicalismo neoliberal, expressão da onda mundial conservadora, como a Força Sindical, de outro, a inflexão da CUT, que parecia não estar preparada para esse momento de transição, falhando em elaborar e propor alternativas econômicas contrárias ao padrão de desenvolvimento capitalista existente no Brasil (ANTUNES, 2002; ANTUNES; SILVA, 2015).

A estratégia sindical nos anos 1990 é distinta daquela desenvolvida nas décadas anteriores. A principal questão na agenda sindical é a defesa do emprego, a participação nos resultados, a discussão das mudanças na gestão e a organização do trabalho, a flexibilização da jornada de trabalho, etc. Ou seja, a preocupação em atenuar ao máximo os efeitos que o neoliberalismo tem trazido para os trabalhadores, principalmente na alarmante perda de postos de trabalho (RODRIGUES, 2002). Entretanto, esse Novo Sindicalismo também encontrou contradições contundentes, como o apoio às privatizações, as desregulamentações e as flexibilizações do mercado de trabalho já no mandato do Presidente Collor de Mello (PRN), como por exemplo a desmobilização de greves, o incentivo a contratos de trabalho flexíveis e a privatização da Mafersa e da Usiminas, por exemplo (TRÓPIA, 2009).

A tendência neoliberal nos anos 1990 se reproduziu também na figura de Fernando Henrique Cardoso (PSDB), que alinhado com Consenso de Washington, pôs em prática um conjunto de reformas que depreciou o conteúdo nacionalista da Carta Magna, extinguindo certas restrições ao capital externo, como a Emenda Constitucional (EC) no 5, de 15/08/1995, tratou do fim do monopólio estatal da distribuição de gás canalizado; A EC ñ 6, de 15/08/1995, que eliminou o tratamento jurídico privilegiado (distinção não isonômica) concedido às firmas brasileiras de capital nacional; a EC $\mathrm{n}^{\mathrm{o}} 7$, de 15/08/1995, autorizou que embarcações estrangeiras explorassem a navegação de interior e de cabotagem no país; a EC $\mathrm{n}^{\mathrm{o}}$ 8, de 15/08/1995, permitiu a exploração do setor de telecomunicações pelas empresas privadas; e a EC $n^{\circ}$ 9, de 09/11/1995, alterou a redação do parágrafo $1^{\circ}$ do artigo 177 da Carta Magna, 
quebrando o monopólio da União em setores econômicos estratégicos: petróleo, gás natural e minério nuclear (SILVA; SALIBA, 2015).

Nos anos 2000, o acontecimento mais marcante foi a eleição de Luiz Inácio Lula da Silva (PT) à presidência do Brasil. Emissário do "novo sindicalismo", Lula chegou à presidência com um intenso apoio dos movimentos sociais, de uma parcela significativa do sindicalismo e de vastos setores das classes trabalhadoras. Apesar das contradições entre forças político-ideológicas da gestão, no geral, os sindicatos apresentaram um período de ganhos reais de salário e de ampliação do emprego formal, além de um conjunto de políticas públicas voltadas para a população mais excluída da sociedade, dificilmente abarcada pela representação das entidades sindicais (SINGER, 2012). As vitórias da classe sindical se demonstraram pírricas à medida que elas foram cada vez mais atreladas ao Estado, que passou a evidenciar uma clara contradição e desmobilização, que viria se tornar fatal no governo de Dilma Rousseff (PT) em 2015, pois abriu a possibilidade de forças conservadoras reverterem as conquistas sociais em virtude de uma agenda restritiva das demandas sociais dos trabalhadores (TRÓPIA, 2009; HAZAN; POLI, 2017). Após o seu impeachment (2016), o presidente empossado Michel Temer não demorou para aprovar medidas que traduzissem essa onda de precarização do trabalho causada por uma dura austeridade imposta ao cidadão brasileiro. Austeridade esta que teve sua “personificação" na EC n 95, de 15/12/2016, que alterou o Ato das Disposições Constitucionais Transitórias (ADCT) para instituir o Novo Regime Fiscal. Resumidamente, trata-se de limitar os gastos das despesas primárias de um exercício ao valor do ano anterior, corrigido pela variação do Índice Nacional de Preços ao Consumidor Amplo (IPCA). Esse novo regime fiscal terá duração de 20 anos, contados a partir de 2017. A referida EC apenas considera como variável de ajuste as despesas primárias. Os gastos com pagamento dos juros e amortização da dívida pública ficaram fora desse "teto".

Seguindo a mesma linha e dessa vez afetando diretamente as relações trabalhistas, foi sancionada a Lei no 13.429, de 31/03/2017, apelidada de Lei da Terceirização. Ela permite às empresas terceirizar quaisquer atividades, não apenas atividades acessórias como era antes permitido. Também regulamenta aspectos do trabalho temporário, aumentando de três para seis meses o tempo máximo de sua duração, com possibilidade de extensão por mais 90 dias e prevê que o trabalhador terceirizado só poderá cobrar o pagamento de direitos trabalhistas da empresa tomadora de serviço após se esgotarem os bens da empresa terceirizada. 
Foi aprovada também a Lei n 13.467 , de 13/07/2017 que altera a Consolidação das Leis do Trabalho (CLT) que coloca o trabalhador e a atividade sindical brasileira em vulnerabilidade em diversos pontos, como: o fim da contribuição sindical obrigatória; fim da obrigatoriedade de homologação sindical das rescisões e; autoriza demissões em massa sem a necessidade de negociação coletiva.

Já a Reforma da Previdência, apresentada no dia 20 de fevereiro de 2019 ao Congresso

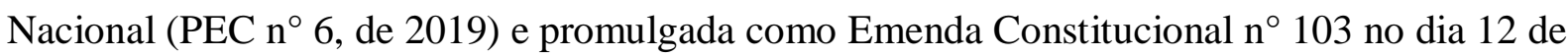
novembro do mesmo ano, veio em consonância com a $E C \mathrm{n}^{\circ} 95$, ou seja, com o pretexto de enxugar as contas públicas. Resumidamente, as principais medidas foram: maior rigidez nas regras de transição; limitação de conversão de tempos especiais em comuns; redução no valor do benefício decorrente de uma formulação mais rígida; unificação de diversas modalidades; e o aumento das idades mínimas necessárias para requisição da aposentadoria, podendo chegar a 40 anos para a sua integralidade.

Tais acontecimentos são recentes, ficando em aberto qual o impacto dessas mudanças sobre os sindicatos e as centrais sindicais, se serão capazes de romper a barreira imposta pelo capital entre a luta sindical e a luta parlamentar, entre a luta econômica e a luta política, articulando e fundindo as lutas sociais, extraparlamentares, que dão vida às ações de classe.

\section{ERGOLOGIA: UMA LENTE TEÓRICA PARA O ESTUDO DO TRABALHO}

Por ser complexo para se compreender e estudar a partir de uma única disciplina do conhecimento, a Ergologia coloca em dialética o conjunto dos saberes elaborados pelas outras disciplinas. Quando isso é feito, não somente se tem uma visão mais realista e completa da atividade de trabalho humano, mas se descobre outra dimensão (TRINQUET, 2010).

\footnotetext{
Historicamente falando, à medida que as ciências são desenvolvidas, sentimos a necessidade de nos especializarmos, para conhecer, cada vez mais profundamente, os segredos, os enigmas dos sujeitos abordados. [...]. Todavia, o preço da especialização acaba nos levando a perder de vista o global, o geral. [...] É condição sine qua non colocar em dialética todos os conhecimentos precisos e pontuais para encontrar o global. No domínio da atividade humana, é o que a ergologia tenta fazer, conduzindose, dialeticamente, com as descobertas das ciências especializadas, como: a ergonomia, a sociologia, a psicologia, a medicina, a filosofia, a economia, a engenharia, as ciências da educação, etc. (TRINQUET, 2010, p. 94).
} 
Ao se colocar todas essas disciplinas em debate sobre as atividades, tanto dentro quanto fora do trabalho, descobrem-se novos achados, novos conceitos, que abrem novas perspectivas e horizontes ao conhecimento.

Ergologia, segundo Durrive e Schwartz (2008) é uma disciplina do pensamento que reconhece a atividade como debate de normas. E tenta desenvolver-se simultaneamente no campo das práticas sociais e com a finalidade de elaboração de saberes formais por toda a parte onde for possível.

Considerando que a ergologia é um estudo da atividade humana no trabalho, Trinquet (2010) caracteriza o seu objetivo e método: o objetivo consiste em conhecer melhor a realidade da atividade laboriosa levando em consideração toda a sua complexidade, analisar sob quais condições ela se realiza de fato, o que permite melhor organizá-la e, portanto, torná-la mais eficaz e rentável, tanto em seus aspectos econômicos quanto sociais e humanos, sem ter de forçar a sua intensidade e/ou sua cadência. Já o seu método põe em diálogo a multidisciplinaridade dialética dos saberes eruditos e dos saberes de experiência. Conforme definições ergológicas: a prática dos processos socráticos em duplo sentido, entre os saberes constituídos e os saberes investidos.

A Ergologia para se referir ao trabalhador ou as suas atividades usa o conceito de “corpo-si”. Este termo quer ilustrar o trabalhador no mais íntimo da atividade, como um ser complexo e enigmático que oferece resistência às prescrições, ao ordinário (HOLZ; BIANCO, 2014). Toda a presença no si do histórico da situação de trabalho (mas não só do trabalho) passa muito pelas relações humanas, por todas as sensações, por tudo que é registrado pelo corpo e pela memória.

O corpo é o que não se pode objetivar, apreender nem na clara consciência, nem nos debates subjetivos frequentemente ouvidos. Trata-se da extraordinária complexidade do que se passa, desse "destino a viver", e remete ao fato de que o "corpo-si" é um elemento de transgressão, considerando um debate filosófico. Ou seja, quando a filosofia se confrontou com o "fazer industrioso", ela se interrogou: como a humanidade fabrica? Como ela produz? Há o entendimento, há a razão, há vontade, e há também o corpo, e neste corpo há paixões (SCHWARTZ; DUC; DURRIVE, 2010; ARAÚJO et al., 2019).

A atividade, como o trabalho, mergulha suas bases no mais obscuro do corpo, e por contrapartida ela tem a ver com o que há de mais cultural, histórico e moral. Não há limiar que sintetize o "corpo-si", entretanto, Schwartz (2010c) aponta três dimensões fundamentais: 1) 
existe um nível do si que é o corpo inserido na vida; é o corpo a partir do fato de que somos parte do mundo da vida. E desse ponto de vista, há continuidades, comensurabilidades do humano com os outros seres vivos. As pessoas se prendem a conceitos, à cultura, às relações sociais, às regras, às normas etc. Enfim, o "si" é inseparável desse movimento, da evolução da vida; 2) ao mesmo tempo, o "si" é domado. Ele está, desde o nascimento, em um universo que é atravessado e saturado de valores, de histórias, de conflitos, de normas antagônicas. É a característica do meio: nossa vida acontece nas instituições e tudo é perpassado de técnicas, normas, valores e de construções do social. O "si”, portanto está completamente imerso nisso; e 3) o "si" é também a história psíquica, ou seja, a história da passagem do ser humano a um mundo que ele não criou, no qual ele é mortal e há todos os tipos de normas, regras e leis com as quais seu desejo deve se defrontar, e isto também é história. Portanto, o "si" acumula tudo isso, e o menor dos atos de trabalho remete a essas três dimensões. Esse "corpo-si" é então uma expressão mais problemática do que a noção de subjetividade.

Quando Schwartz (2010c) diz que trabalho é uso de si, decorre à ideia de que não há execução, mas uso, pois, é o indivíduo no seu ser que é convocado; são recursos e capacidades de uma vastidão que vai além do que a tarefa cotidiana requer explicitamente. $\mathrm{O}$ trabalho, que é uma atividade complexa e por vezes surpreendente, exige do trabalhador um "fazer de outra forma". Ele reorganiza o trabalho demandado, fazendo escolhas e executando-o de outro modo, e essa reorganização está unida à forma como ele sente e distingue o mundo. Isso porque os humanos são singulares e suas experiências e histórias intervêm na realização do trabalho, o que induz todo ato laboral a ser um uso de si por si e pelos outros na coletividade, repleta de troca de valores (HOLZ; BIANCO, 2014; SCHWARTZ, 2014).

O uso de si pelos outros leva a um conjunto de regulamentos múltiplos, pois os "outros" podem ser os colegas de trabalho ou ainda podem estar fora do contorno imediato; podem ser os seus gerentes; ou os seus empregadores; ou também os que prescrevem e as normas técnicas, científicas, organizacionais, hierárquicas ou gestionárias (TRINQUET, 2010; ARAÚJO et al., 2019). O trabalhador ao fazer escolhas sobre esse ou aquele ofício, transforma o trabalho em uma realidade intensamente coletiva e individual, visto que é profundamente singular (ARAÚJO et al., 2019).

As "dramáticas do uso de si” são a necessidade de fazer escolhas neste vasto espectro que é o saber humano e a arbitragem entre o diferente e o contraditório (SCHWARTZ, 2011). Ou seja, há sempre uma história à espera do trabalhador, história essa determinada por suas 
múltiplas escolhas. Existe o risco de o indivíduo falhar, desapontar ou dificultar contido nas escolhas, porém somente por ele ter este poder, escolhe viver, assumindo também as consequências de cada ato (HOLZ; BIANCO, 2014; SCHWARTZ, 2014; ARAÚJO et al., 2019).

Evocar dramáticas do uso de si é entrever o que há de mais extraordinário em toda a atividade, especialmente em toda a atividade de trabalho. É a necessidade de articular, e frequentemente, num mesmo instante, de colocar em sinergia ingredientes de competência. Cada um articula à sua maneira, com sua história e seu perfil, isto é, consegue colocar em comunicação dimensões totalmente heterogêneas, como as do saber codificado; as do saber da história e na história; e a relação em termos de valores com o meio, meio no qual se vive e o que te faz viver (SCHWARTZ, 2010a).

Já conceito de trabalho prescrito tem suas raízes na Ergonomia. Consideram-se prescrições às ordens emitidas pela hierarquia (oralmente ou por escrito) os procedimentos definidos pela realização do trabalho (receitas, configurações, parâmetros e regulamentos), as normas técnicas, de segurança, ou outras que devem ser seguidas, os objetivos explicitados aos trabalhadores em termos de qualidade, prazo e profundidade. Trabalho prescrito envolve, ainda, as condições dadas para a realização do trabalho (TELLES; ALVAREZ, 2004).

Para a Ergologia, o conceito de trabalho prescrito está contido nas "normas antecedentes" (SCHWARTZ, 2011). Estas incluem também os saberes científicos, técnicos, as regras jurídicas, as experiências capitalizadas, tudo o que antecipe a atividade futura de trabalho, antes mesmo que a pessoa tenha começado a agir (ARAÚJO et al., 2019).

Schwartz (2010b) destaca três aspectos da noção de normas antecedentes, são esses: 1) elas abarcam restrições de execução determinadas de modo heterogêneo, porque há nelas algo que pode ser identificado como a expressão de um dogmatismo científico legitimado por um poder social; 2) não se pode considerar unicamente essa dimensão ligada sobretudo à imposição, pois as normas antecedentes são também construções históricas. Assim, se trata de um patrimônio conceitual, científico e cultural, no qual podemos identificar, entre outros, o nível técnico-cientifico atingido e a história sempre particular que conduziu a tal nível, como as práticas, as linguagens, os modos de vida etc. Trata-se de experiência acumulada que pode ser tomada como patrimônio da humanidade em sua totalidade; 3) indicam igualmente "valores", termo também da ergologia que se refere a elementos do bem comum, que são redimensionados nas organizações, nos ambientes de trabalho e na sua relação com o meio 
externo. Na verdade, esses elementos estão presentes na dimensão político-jurídica. Aí os valores do bem comum são dimensionados, ou seja, dotados de instituições, de recursos, de normas que possam atender aos anseios das pessoas que vivem em sociedade. Esses valores são objeto de debates, conflitos e arbitragens políticas. Pode-se dizer que os valores transcendem como ideias reguladoras as conjunturas nas quais vão operar, mas que devem funcionar com princípios de ação em todas as circunstâncias (SCHWARTZ; DUC; DURRIVE, 2010; DURAFFOURG; DUC; DURRIVE, 2010; ARAÚJO et al., 2019).

De certa maneira uma norma está interligada não somente a um valor, mas a um "mundo de valores", eles estão sempre presentes em cada atividade do indivíduo. Se por um lado são os valores que mantém o trabalhador conexo com o meio social em que ele está inserido, como por exemplo a idea de justiça, por outro lado um turbilhão de valores latentes em confronto com normas pode causar frustração, dilemas e desgaste psicológico. Parece que por decorrência disso as normas foram criadas, para dar uma tradução operacional e objetiva do que está em jogo neste "mundo de valores", tentar reduzir o ser social com toda a sua complexidade às características de uma máquina.

Essas normas e valores em jogo em cada micro da atividade, em cada escolha realizada, consciente ou inconscientemente, leva a uma reconfiguração das normas prescritas, a que Schwartz (2011) chama de "renormalização".

[...] renormalizações são as múltiplas gestões de variabilidades, de furos das normas, de tessitura de redes humanas, de canais de transmissão que toda situação de trabalho requeira, sem, no entanto, jamais antecipar o que elas serão, na medida em que essas renormalizações são portadas por seres e grupos humanos sempre singulares, em situações de trabalho, elas mesmas, também sempre singulares (SCHWARTZ, 2011, p. 34).

As renormalizações, portanto, são processos de retrabalho das normas antecedentes que acontecem em todas as situações de trabalho, no decorrer de um desencontro de valores que as circundam. Então a possibilidade de fazer com que esses valores sejam revelados em suas micro-histórias é de contribuição direta da ergologia.

As ações humanas realizadas ao longo do tempo em um determinado lugar, ou seja, a história é representada como uma dialética permanente em um espaço polarizado: em um polo está a lógica do mercado, da troca de valores monetários, dos custos, da medição e das vantagens competitivas; em outro polo, antagonizando com o primeiro, está a lógica do interesse geral, do bem comum, o expresso e gerido acima dos interesses individuais, a 
salvaguarda dos valores humanos, como o serviço público, a saúde, o acesso à educação, cultura e dignidade (SCHWARTZ; DURRIVE, 2015).

De certa forma, esses dois polos dialéticos podem ilustrar as tensões atuais entre a democracia e o mercado, o embate entre as lutas e as conquistas sociopolíticas, a garantia de direitos fundamentais versus as pressões ligadas a globalização financeira de precarização do trabalho e ao princípio de solidariedade. O que há, contudo, é um debate aberto, uma busca incessante ao equilíbrio dinâmico entre os valores não dimensionados e valores dimensionados. Esses dois polos, econômico e político não se ignoram, eles estão em constante embate e agem um sobre o outro (SCHWARTZ; DURRIVE, 2015).

Entretanto, segundo Schwartz e Durrive (2015), somente esses dois campos não são capazes de explicar como tais valores realmente fazem história, preponderantes no micro da atividade no instante em que elas ocorrem. A Ergologia, por fim, afirma que há um terceiro polo no espaço/tempo em que a história se realiza, este é o polo da atividade industriosa. É a partir deste polo que cada um reavalia suas normas antecedentes até no ínfimo de sua atividade, retrabalha seus valores adquiridos em outros espaços e, então, emerge reservas de alternativas, o "fazer de outro modo".

\section{ASPECTOS METODOLÓGICOS}

A proposta metodológica escolhida fundamenta-se numa perspectiva qualitativa e dialógica, que valoriza a fala, a escuta, a troca, a reflexão sobre a trajetória do sujeito entrevistado, oportunizando não somente o entendimento do vivido social, mas, apreendendo saberes ao ultrapassar limites das sapiências disciplinares (GOMIDE; NOGUEIRA; BARROS, 2010; BARROS; SILVA, 2002). A pesquisa qualitativa é um meio para dar voz aos indivíduos, ao invés de tomá-las como coisas (GASKELL, 2000). O método da abordagem biográfica possibilita um caminho para acessar processos que sustentam a sociedade e suas histórias sociais, que são subjetivamente vividas em dimensões - psicológicas, culturais, econômicas, sociais - históricas e atuais (LÉVY, 2000). A abordagem biográfica é uma sociologia que se caracteriza pela pesquisa empírica, que valoriza o trabalho de campo como uma prática corrente. Assim, não existe uma receita que deve ser seguida para recolher uma história de vida, no entanto, considera-se a singularidade de cada história e o caminho para compreender tal universo. Utiliza métodos originais (documentos pessoais e o recolhimento de histórias de vida) 
para a realização de pesquisa, assim, o método biográfico é rico e oportuno para pesquisas, intervenções e formações (BARROS; LOPES, 2014).

Esta pesquisa propôs uma produção de dados que se ocupa com a subjetividade via histórias contadas pelo sujeito pesquisado e o olhar do pesquisador em questão. Assim, o pesquisador é um intérprete da realidade pesquisada e sua postura teórico-epistemológica, produzirá conhecimento para a comunidade acadêmica com relevância social. A construção da realidade é resultante da vida cotidiana das pessoas, que nem sempre escolhem as condições já estabelecidas (GASKELL, 2000).

A escolha do colaborador — entrevistado — foi norteada por uma preocupação a partir da posição deste no sindicato e do significado de sua experiência. Assim, optou-se por selecionar o indivíduo que é vigilante há 15 anos, sindicalista desde 2013, ocupando o cargo de diretor jurídico no Sindicato dos empregados nas empresas de transporte de valores, escolta armada, ronda motorizada, monitoramento eletrônico e via satélite, agente de segurança pessoal e patrimonial, segurança e vigilância em geral.

O local da pesquisa foi tanto a casa do entrevistado quanto a própria sede do sindicato, proporcionando também ao pesquisador tanto a observação do espaço físico da sede, quanto à consulta a documentos e fotografias históricas do sindicato.

Para que uma pesquisa seja feita com qualidade é necessária a adoção de um método sistemático e organizado de obtenção dos dados, baseando-se no referencial teórico (GODOI; MELLO; SILVA, 2010). A mediação teórico-conceitual esteve presente ao longo de toda pesquisa. Optou-se por realizar entrevistas abertas para auxiliar no método de história oral de vida. Mas por que história oral como método para este trabalho?

O uso da História Oral converge no nosso entender com os interesses epistemológicos da Ergologia, uma analítica complexa, pois esta pretende que o trabalhador reflita sobre o seu trabalho e seus saberes, permitindo certo empoderamento e transformação dos sujeitos. A intervenção na Ergologia tem como objetivo incitar aqueles que vivem e trabalham a pôr em palavras um ponto de vista sobre a sua atividade, a fim de torná-la comunicável e de submetêla à confrontação de saberes (SCHWARTZ, 2011). A História Oral então permite aos sujeitos reflexão e consciência social, que auxilia também nesses processos de subjetivação. Ela "trata os indivíduos como capazes de serem construtores e participantes da história" (CAPELLE; BORGES; MIRANDA, 2010, p. 6). Ou seja, epistemologicamente elas são compatíveis para abordagem do trabalho humano e das dimensões históricas a ele relacionadas. 
É importante destacar ainda a tipologia da história oral, segundo Meihy (2002) há três vertentes de história oral: 1) História oral de vida; 2) História oral temática; e 3) Tradição oral. História oral neste trabalho refere-se à História oral de vida, pelas seguintes características: o sujeito primordial é o depoente; retrato oficial do depoente; a verdade está na versão por ele apresentada; o narrador é soberano para revelar ou ocultar casos, situações e pessoas; as perguntas das entrevistas devem ser amplas, sempre colocadas em grandes blocos, de forma indicativa dos grandes acontecimentos, e o entrevistador não deve contestar o entrevistado.

Em conformidade com o método foram realizadas entrevistas abertas, cedendo total liberdade para o colaborador retomar, sentir e expor suas memórias em momento ímpar por meio de encontros, totalizando seis ao todo, com cerca de uma hora de duração cada entrevista. Recomenda-se de seis a doze entrevistas (MEIHY, 2002), dependendo da pesquisa e do entrevistado. O colaborador teve autonomia para contar livremente suas histórias de vida, entretanto, quando estritamente necessário, o pesquisador fez intervenções pontuais.

Para a produção de dados, fora confeccionado um roteiro de entrevista com poucos tópicos, no sentido "me conte sua história de vida" (BARROS; LOPES, 2014) deixando o colaborador à vontade e trilhando a conversa nos rumos compatíveis com o referencial teórico. Os tópicos são: história familiar; história educacional; história profissional e; experiência vivida na atuação como sindicalista.

As dificuldades da produção de dados já apareceram logo no primeiro momento. Vários trabalhadores que foram consultados para participar da pesquisa ficaram receosos em imergir e externalizar tanto seu passado pessoal quanto assuntos políticos delicados para o sindicato, então, o entrevistado exercia seu direito exposto no termo de consentimento livre e esclarecido e abandonava a pesquisa em seu início ou metade, restando ao pesquisador eliminar as gravações e transcrições realizadas e voltar ao ponto zero, na escolha de outro profissional para participar da pesquisa.

O primeiro contato com o sindicalista participante ocorreu em fevereiro de 2019. Ele aceitou prontamente participar, mas alertou que o pesquisador teria que ser flexível em seus horários para poder realizar a pesquisa, pois a escala de trabalho era apertadíssima, com trabalhos noturnos e em finais de semana tanto como vigilante quanto sindicalista. Portanto, a maioria das entrevistas aconteceu na residência do profissional.

Como o método propõe investigar as narrativas não somente de acontecimentos realizados no trabalho, mas da vida do indivíduo como um todo, houve também uma dificuldade 
para extrair suas memórias mais delicadas. Somente com o tempo de interação pesquisadorcolaborador foi possível obter tais narrativas.

O gravador de voz também apresentou falhas pontuais quando o colaborador baixava demais o tom de voz, mas nada que comprometesse o entendimento ao transcrever.

A pesquisa documental acerca do sindicato, também não foi satisfatória. Devido à história conturbada que a entidade teve, o passado desta parece que foi apagado, por consequência ou até mesmo propositalmente em certos aspectos, como apareceu nas narrativas no decorrer da pesquisa.

Para proteger a identidade do profissional, lhe foi perguntado com qual nome gostaria de ser mencionado, ele escolheu "Juvenal".

Por fim, as características das categorias emergiram com as narrativas, portanto foram definidas a posteriori.

É importante se ter em mente que a abordagem ergológica foi de vital autoridade para as análises, isto porque, como o método demanda, é necessário sempre trilhar nos caminhos que o aporte teórico proporciona, para então, atingir os objetivos propostos.

\section{ANÁLISE DA HISTÓRIA DE VIDA DE JUVENAL}

A abordagem ergológica foi o referencial teórico base para analisar os dados. Tal análise se baseia em categorias que emergem dos conceitos da ergologia cruzadas com as narrativas, em como Juvenal construiu a sua história: suas escolhas, sua doação, sua transgressão; ou seja, toda sua ação e sentimentos envolvidos em sua trajetória de vida. Tais categorias são apresentadas em seguida. Porém, a Fig. 1 adianta o esquema analítico: 
Figura 1. Esquema ergológico de análise dos dados em história oral

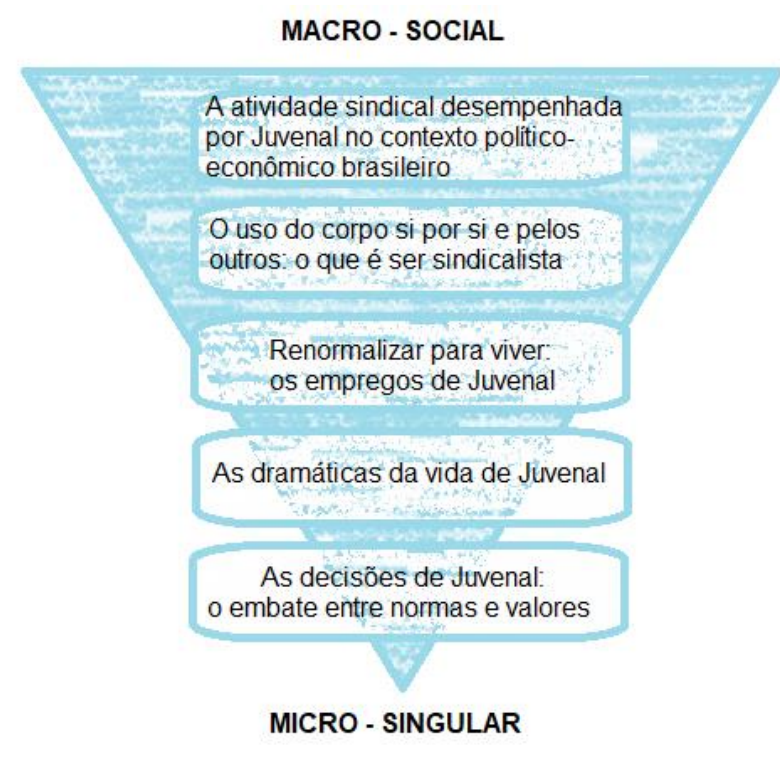

\subsection{AS DECISÕES DE JUVENAL: O EMBATE ENTRE NORMAS E VALORES}

É impossível pensar o ser humano sem levar em conta os valores apreendidos ao longo de sua existência, pois eles são mediadores de comportamentos, condutores da vida social. Por meio de relações interpessoais os valores orientam os sujeitos em suas escolhas.

Entretanto, viver exclusivamente para a reprodução de valores que perpassam sua sociedade não é de fato viver, é patogênico. Cada indivíduo procura não ser uma peça de tabuleiro do meio (SCHWARTZ, 2015). Aparentemente foi por isso que desde criança Juvenal tomou escolhas que driblavam o óbvio e o imposto sobre ele: "Quando voltava pra casa o pau quebrava, porque eu saia escondido, né? Fugia da escola, mas era bom”. Por repetidas vezes o garoto Juvenal mesmo sabendo que apanharia, optou por se divertir com os colegas na rua e pagar o preço mais tarde. Apesar das desobediências, Juvenal respeitava e apreciava as lições de sua mãe, lições que fizeram muita falta depois que ela partiu.

Ao contrário da relação com sua mãe, o relacionamento com seu pai sempre foi tenso. Por estar sempre longe de sua família, o pai de Juvenal parece não ter conquistado a legitimidade de ser um provedor de valores para o filho, e, por muitas vezes tentou exercê-lo de forma violenta e autoritária, o que complicou ainda mais a relação entre pai e filho. Estar inserido em um universo de valores compele atrelar-se a princípios que farão direta interferência no enfrentamento dos conflitos vivenciados pelo indivíduo ao longo de sua vida 
(SCHWARTZ, 2015), e foi em um desses conflitos, uma briga em que seu pai não aceitava o seu namoro, que Juvenal decidiu sair de casa aos dezesseis anos.

\footnotetext{
"Nosso elo era a figura da mamãe, ela que mantinha todo mundo junto. Por mais errado que um tivesse ela abraçava e trazia, chamava atenção de um e do outro, e a fraternidade permanecia. Aí quando ela faleceu tudo se rompeu".

"[A família ainda tinha o pai, mas] como nós crescemos, cada um conseguiu sua autonomia, pelo menos os quatro mais velhos... nós somos em sete, então os quatro mais velhos começaram a atingir a sua autonomia, então a gente não dependia dele mais, entendeu? Aquela questão de "ah, você tem que tá em casa" "não, ué, aqui nós tem autonomia".
}

A norma de seu pai chocou-se com a vontade e com as convicções de Juvenal, que buscou autonomia com sua namorada bem longe de casa, na já conhecida Cubatão. Lá eles logo arrumaram emprego, tiveram uma filha e se casaram. Em um olhar distante parecia estar tudo bem, mas no seio da jovem família havia muitas desavenças conjugais. Os conflitos se intensificaram a ponto de o casal largar tudo e voltar para Camaçari, pois apesar de Juvenal ser bem imaturo à época, presava sempre pela união da família. Ele abriu mão de muita coisa por ela e não desistiria dela facilmente. A luta e o sacrifício em prol da família é um valor que Juvenal desde criança assimilou de sua mãe.

No primeiro instante o convívio entre Juvenal e a esposa pareceu ter melhorado. Ambos estavam próximos de suas respectivas famílias, o que ajudou bastante a aliviar as tensões entre os dois. Juvenal logo arrumou emprego no setor industrial e com o tempo gozou de uma rápida ascensão profissional. A responsabilidade, entretanto, não ascendeu na mesma velocidade, as sucessivas noitadas de Juvenal com seus colegas de trabalho acabaram por minar ainda mais o seu casamento: "Mas não sei que cargas d'água, eu muito doido também, meio irresponsável, quando resolvia fazer umas festinhas, era um dia, dois. Falta de responsabilidade, nunca tive compromisso nenhum, aí ela se cansou”. Não há evidencias o suficiente para afirmar que essas "festinhas" eram algo normalizado ou imposto inconscientemente pelo clima organizacional dentro da empresa onde Juvenal trabalhava, mas fato é que ele cedeu demais, ferindo assim seu casamento.

O ultimato de sua esposa para salvar o casamento fez Juvenal tomar mais uma importante decisão para sua vida, se mudar novamente. Sua esposa acreditou que, longe da Bahia, Juvenal não perderia mais o controle, então ele, ainda com seu ideal de acreditar e lutar pela família, decidiu salvar o casamento e acatar ao ultimato da esposa. "Larguei meu serviço, eu ganhava na época mais ou menos 10 salários, aí fui pro Rio Grande do Sul, aventurar pra 
ganhar 2. Sem ter casa, sem ter nada. [...] viver de favor. Não durou muito não. Aí complicou mais. O relacionamento foi por água abaixo, cara".

Há de se refletir que o padrão de vida tranquilo que Juvenal obtivera na Bahia virou a norma, e quando ele não conseguiu mais algo nem perto disso, mesmo com todo seu engajamento, houve uma severa frustração já que os valores também são ideias reguladoras, funcionam como princípios de ação em todas as circunstâncias (DURAFFOURG; DUC; DURRIVE, 2010). Juvenal viu o que ele mais presava se desfazer, a família. Sua esposa rompeu o casamento e voltou para a Bahia com os seus filhos, o deixando sozinho no Sul.

A partir daí, o valor que parecia ser o norteador de sua vida, a família, se esvaiu, e Juvenal ficou sem rumo, sem propósito. Isso ilustra o que Schwartz (2015) chama de "declinação", quando há uma ordenação, uma hierarquização de valores. A declinação de valores é sempre localizada por cada um na situação e pela situação, e nelas é preciso viver, operar uma situação de sempre fazer história, a relação com o mundo de valores está ligada a própria história do sujeito, que é parte interessada da história coletiva (SCHWARTZ, 2015).

Juvenal assim perdeu o interesse em si mesmo, e pouco a pouco ele foi se privando de escrever sua história até perder o controle de sua vida, chegando a experimentar durante muito tempo viver em condição de rua.

\footnotetext{
"Muito triste, eu tinha tudo. Tinha dinheiro, casa, família... agora não tenho nada. Não tenho moral, não tinha porra nenhuma. Tempo triste. Muito triste. Mas tem uma coisa: pra quem nasce pra ser vencedor, não é seu destino você cair, você dá a volta por cima. Única coisa que precisa ter é humildade, ser humilde. Voltar ao começo. Foi isso que eu fiz. Joguei por terra meu orgulho, minha soberba, minha ideia de achar que eu era acima de todo mundo e reconhecer que eu não era porra nenhuma. No dia que eu reconheci que eu não era nada, aí eu comecei a dar a volta por cima. Comecei a superar as coisas. Difícil. Três anos de luta".
}

O embate mais intenso entre normas e valores travado por Juvenal foi nesse período. Ele repensou, de modo mais amargo, o que ele era, o que ele precisaria superar para voltar a ser o escritor de sua própria história, porque afinal ela é perpetuamente recriada por meio do inevitável debate de valores. E ninguém escapa desse compromisso consigo mesmo e com a vida (SCHWARTZ; DURRIVE, 2015).

"Voltar ao começo" para Juvenal foi repensar todo o seu mundo de valores. Pelos relatos, somente quando houve essa auto confrontação é que ele começou a assumir novamente o controle de sua própria vida, de seu próprio corpo-si (SCHWARTZ, 2010c). As pessoas se prendem a conceitos, às regras, normas e relações sociais, e por isso, o "si" é domado, saturado 
de valores que guiam o indivíduo para o razoável, o normal e o compatível com a vida social no qual está inserido. A transgressão nesse mundo socialmente construído pode ser conflituosa (SCHWARTZ 2010c), e Juvenal parece ter tido dois confrontos em seu corpo-si, o primeiro quando ele passou a estar à margem da sociedade e o segundo para se reinserir na vida social.

\subsection{AS DRAMÁTICAS DA VIDA DE JUVENAL}

As "dramáticas" no sentido ergológico vão além de uma situação comovente, que envolve sofrimento ou aflição. O termo "dramática" é vinculado ao conceito de corpo-si, para retratar que há sempre uma dimensão do corpo simultaneamente singular, biológica e histórica, onde se realizam escolhas e se acumulam experiências das mais diversas formas (HOLZ; BIANCO, 2014).

O acontecimento-chave para se entender o desenrolar da vida de Juvenal, foi, a julgar pelos depoimentos, o falecimento de sua mãe. A ausência da referência materna parece tê-lo deixado sem rumo. "Eu sempre fui família. Família assim, a matriarca tomando conta. Filhinho da mamãe? Não, [...] eu só tinha uma referência de mãe, era ela que me orientava”. Sem dúvidas foi a primeira, uma das mais importantes e correlacionada a todas as outras dramáticas que Juvenal teve que enfrentar em sua vida. "Aí depois que mamãe morreu cada um foi para um canto. Foi uma sequência. A minha mãe faleceu, dois anos depois o meu pai faleceu, aí meu irmão [...] faleceu também então daí ficou um para um lado, outro pro outro". Foi nesse momento de luto que Juvenal se viu forçado a evocar as dramáticas do uso de si.

Porém, entre um luto e outro, Juvenal se envolveu em uma dramática há muito tempo latente, um embate com seu pai por causa da não aceitação de sua namorada. Sem a presença da matriarca para mediar os conflitos, o choque entre os dois parecia inevitável, já que o pai exercia uma autoridade bruta que Juvenal nunca a legitimou, e as normas impostas por ele não pareciam coerentes para o jovem, que acabou por sair de casa ainda com seus dezesseis anos. Schwartz (2010a) e Trinquet (2010) afirmam que acionar as dramáticas do uso de si é hesitar, pois há uma consciência que precisa calcular e escolher um dentre tantos outros caminhos, e, consequentemente, lidar com essa escolha. Pelos relatos, Juvenal aparenta ter tomado a decisão de sair de casa por impulso, todavia não se pode descartar a história, tanto entre pai e filho quanto a história individual de ambos, cada evento, dramática, microhistória ocorrida no passado foi preponderante para a sua tomada de decisão. 
No âmbito do trabalho, pode-se destacar o drama que Juvenal viveu quando foi demitido de seu emprego de mecânico industrial em Dias D’ávila. Já esposo e pai de dois filhos, Juvenal estava completamente adaptado e estabilizado em seu trabalho, inclusive com promoções frequentes, respeito e admiração de seus superiores. Tudo isso teve um amargo final quando ele entrou em uma discussão com um colega de trabalho:

\footnotetext{
"Brigava com um e com outro, discutia, tanto que até perdi o emprego uma vez por causa disso. Porque assim, quem não participa, não se envolve, a gente chama de pelego, aí me botaram um negócio de pelego, fiquei $p$. da vida e soltei umas palavras inadequadas, aí acabei me dando mal nessa história”.
}

Essa demissão abalou bastante Juvenal, porque para ele não era apenas um emprego, era um projeto de vida, era um meio de inserção e reconhecimento de seu corpo-si na coletividade e a base de uma construção histórica (SCHWARTZ, 2011).

A vida profissional de Juvenal ruiu repentinamente, e com ela, a vida conjugal tendia ir para o mesmo caminho. Apesar de todo o esforço para evitar, quando seu casamento acabou e sua esposa voltou para a Bahia com seus filhos, Juvenal se deu conta de que perdera tudo. Foi a dramática que o lançou em outra, tentar sobreviver como pessoa em situação de rua.

O sofrimento enfrentado por Juvenal nesse nebuloso período parece não caber em palavras. Ao descrever essa passagem, por um momento ele só conseguia dizer, com os olhos marejados: "tempo triste, muito triste, muito triste...". Canguilhem (2000), autor caro a ergologia, fala do abismo da impotência como uma patologia, um indivíduo que sofre, nutrindo um sentimento de vida contrariada. Juvenal estava impotente, tudo o que ele lutou para conquistar e manter se esvaiu de sua vida, que perdeu, de certa forma, seu significado. Juvenal entrou pela porta errada. Segundo Safatle (2015) entrar pela porta errada para Canguilhem não é só a perdição, mas o encontro do imprevisto, o imperceptível que vem à tona quando se muda a perspectiva de percepção. Em seu período de negação da realidade, Juvenal esteve errante pelas ruas, praças e banheiros públicos, e a vida que levara antes parecia o lampejo de um passado distante.

Por mais que tentasse, Juvenal não poderia apagar a sua história, e mesmo estando, literalmente, com a água no pescoço, ele conseguiu realizar sua metamorfose, em um processo duplo: 1) de resgate de sua identidade como Juvenal; e 2) renormalizar sua identidade, buscando um velho-novo Juvenal: “A gente busca, cara, no dia a dia. Não sou perfeito, não sou, acho que nunca vou chegar a ser, mas busco pelo menos ser o mínimo. [...], sou falho pra caramba, eu vivo uma busca. Eternamente uma busca, não sei se eu vou encontrar, pelo menos eu busco". 


\subsection{RENORMALIZAR PARA VIVER: OS EMPREGOS DE JUVENAL}

A vida de Juvenal é uma sucessão de renormalizações, como ficou aparente nas narrativas e nas categorias antes analisadas, todavia, este ponto foca nas renormalizações (SCHWARTZ, 2011) ocorridas nos empregos, na sua atividade de trabalho.

Iniciando sua jornada como assalariado, Juvenal menciona que começou como contínuo (office boy), entregando correspondências e realizando alguns serviços administrativos internos, depois foi promovido para escriturário, função que lhe foi confiado mais responsabilidades administrativas e de atendimento ao público. O que chama atenção nesse caso é a menção ao computador entre o jovem contínuo e o homem escriturário. "O computador, eu olhava era um bicho de sete cabeças, gente!" disse Juvenal, evidenciando a complexidade que era para um trabalhador brasileiro da década de 1980 se adaptar à ferramenta informacional. Renormalizar, de fato, é enfrentar um "bicho". Tal fenômeno manifesta-se de um embate entre os valores que cercam as normas antecedentes e os valores dos trabalhadores (SCHWARTZ; DUC; DURRIVE, 2010), portanto, para encarar esse bicho multifacetado chamado computador, Juvenal teve que ir além de suas normas como office boy e engajar seus valores a fim de aprender e adaptar-se a uma nova ferramenta de trabalho. Todo esse processo que se configurou como uma renormalização foi fundamental para a promoção de Juvenal.

De volta para a Bahia, Juvenal conseguiu logo um emprego na área industrial, como ajudante de mecânico, ou seja, bem distante da experiência que teve em São Paulo como bancário. Surpreendentemente, ele se adaptou muito bem ao novo trabalho, sendo promovido diversas vezes, deixando colegas de trabalho mais experientes para trás. Certamente Juvenal adquiriu as competências necessárias para o seu trabalho, mas nas entrelinhas pode-se notar uma renormalização pouco óbvia: ser extrovertido e fazer amizade com seus superiores. Schwartz (2011) afirma que renormalizar também é causar fissuras nas redes humanas, estabelecer novos canais de transmissão. Juvenal percebeu bem a oportunidade de crescer na carreira furando uma norma implícita de impessoalidade e caindo nas graças de seus chefes: "Tinha um bom relacionamento, tanto com o pessoal da engenharia, com os diretores e tudo... [...]. O pessoal quando fazia churrasco, alguma coisa, me convidava, tanto eu quanto ela [esposa]. Aí falei: pô, tá tranquilo!". É importante destacar que esse cenário também causou malefícios, o que o ajudou a ascender, igualmente foi fator preponderante para a sua queda. 
Seus colegas de trabalho nutriram um sentimento de inveja e "armaram" contra ele, ocasionando sua demissão.

Como sindicalista, a renormalização mais difícil e necessária para Juvenal foi modificar seu horário de modo a conseguir trabalhar tanto como vigilante quanto como sindicalista. Mesmo com a remuneração pelo sindicato, ele continuou a trabalhar como vigilante para complementar a renda. Basicamente passou a viver para trabalhar, desempenhando atividades sindicais durante o dia e como vigilante durante a noite, já nas folgas ele aproveita para dormir bastante para poder aguentar a rotina. "[...] Porque também é desgastante trabalhar como vigilante a noite e trabalhar no sindicato de dia rodando de um lado para o outro".

\subsection{O USO DO CORPO-SI: RESUMO DO QUE É SER SINDICALISTA}

"Desde sempre me envolvi com essas questões trabalhistas, movimento, sempre tinha alguma coisa que me levava". É assim que Juvenal percebe o seu interesse pelo sindicalismo, soa como um predestinado. Ele começa sua trajetória na atividade sindical em um momento de indignação com a então atual gestão, que personificada em um déspota corrupto, nada fazia pela sua categoria.

Decidir ingressar em um chapa de oposição, fazer campanha e se engajar para que a condição do sindicato mudasse configura a convocação do uso de si por si e pelos outros (SCHWARTZ, 2014): 1) por si, pois sua própria indignação foi propulsora da ação, porque ele tinha plena consciência de que um sindicato fraco o afetava diretamente; e 2) pelos outros, já que ele sacrificaria o pouco tempo de descanso dele na militância em busca de um sindicato forte não só para ele, mas para seus colegas e todos os trabalhadores da categoria.

Já como sindicalista, Juvenal manteve sua rotina regrada, afinal, é preciso otimizar o seu tempo que se divide entre trabalhar para o sindicato durante o dia e exercer sua profissão de vigilante durante a noite. Apesar de o trabalho sindical parecer flexível, a função de Juvenal como diretor jurídico é bastante normalizado, em alguns momentos até mesmo prescrito (TELLES; ALVAREZ, 2004). Ao chegar em sua sala, ele confere as demandas trabalhistas, filtra as que necessitam de intervenção jurídica, as que demandam visita in loco e as que não procedem. Feito isto, ele forma uma equipe, entra no carro do sindicato e passa o resto do dia visitando postos de trabalho. 
É importante notar que, salvo exceções, essa é a rotina de Juvenal. Inclusive há dias certos para visitar diferentes áreas:

"[...] temos base em A... e em G... (cita cidades). Em A... nós vamos terça e quarta, em G..., quinta e sexta. São subsedes que proporcionam o atendimento ao pessoal de lá. Mais por aqui perto é tudo centralizado no Centro de Vitória, e assim é o nosso dia a dia, corre-corre de um lado para o outro".

É uma prescrição que não está escrita em nenhum lugar, mas que foi normalizado pelo sindicato para o controle das visitas, ou seja, há normas antecedentes (SCHWARTZ, 2011). Inclusive é na visita diária que o uso do corpo-si se faz sempre presente, evoca normas, como a inspeção pragmática do ambiente de trabalho, e evoca valores como a empatia ao ver um trabalhador precarizado (CAVAIGNAC, 2012), é esse engajamento que dita a rotina de Juvenal e resume bem o que é ser sindicalista.

Ao apontar seu pensamento para o futuro, Juvenal demonstra incerteza, principalmente quanto a sua aposentadoria: "Nem sei se eu mesmo vou conseguir me aposentar, por exemplo, tenho 15 anos de contribuição como vigilante, mas já tenho 32 anos de contribuição, mais 3 anos eu completo meus 35 anos e será que eu vou conseguir?”. Ilustra bem o fato de que a luta sindical não é só para a alteridade, é um desafio de toda classe trabalhadora, inclusive um desafio individual, do seu próprio corpo-si (SCHWARTZ, 2010c), que encontra no coletivo a força e motivação para continuar na batalha, por si e pelos outros.

A batalha é cansativa e duradoura, por isso há uma grande preocupação em deixar o legado para os futuros sindicalistas. Juvenal sabe o quanto foi difícil erguer o sindicato do fundo do poço, transformar uma entidade corrupta e patrimonialista em um lugar de confiança, coesão, atuação e competência, e arriscar perder esses valores não está em cogitação. Para isso, Juvenal e os outros diretores desenvolvem uma espécie de treinamento informal, com base na troca de saberes (SCHWARTZ, 2003): "estamos trabalhando com os mais novos, colocando eles na suplência, sempre juntos com a executiva para ir acompanhando e manter o ritmo de trabalho que nós estamos seguindo, para aí passarmos o cadeado. [...] e assim vamos dar sequência, preparando a nova geração". Com isso, Juvenal mostra que sabe que há um nível do "si”" que é mortal, que quando seu corpo-si não mais estará presente, o seu legado estará, com todo seu arcabouço de normas e valores (SCHWARTZ 2010c). Assim Juvenal faz história, deixando marcas em outros corpos. 


\subsection{A ATIVIDADE SINDICAL DESEMPENHADA E CONTEXTUALIZADA}

"Aí eu conheci a tal de classe social ou disputa política e falei assim, rapaz, eu não me conformo com isso não" (Juvenal). A inconformidade que Juvenal nutre ganhou tradução e sentido no movimento sindical no qual passou a fazer parte. Foi quando ele achou o ingrediente que faltava para sua voz ser ouvida: a coletividade. "Eu já tive uma experiência negativa, lá eu percebi que se eu gritar sozinho eu me dou mal, essa foi a minha primeira experiência. Tem que ter coletividade pra falar". O sindicalismo baseia-se na ideia de que, unidos, os trabalhadores podem constranger os capitalistas a negociar condições de trabalho, jornada, salários, etc. É ele que impede a depreciação contínua no mundo do trabalho, se contrapondo à lógica que tem como pressupostos a ideia de que o mercado é auto regulável (laissez-faire), a livre iniciativa individual e a não intervenção estatal na economia (ANTUNES, 1998). O Estado, que, em tese, deveria ser quem vigia e quem garante as condições de trabalho dignas, também é quem provê o desenvolvimento e o progresso do país. O confronto bilateral entre os sindicatos versus mercado se configura em um debate ideológico no qual o Estado pendula.

É conveniente, neste sentido, reivindicar uma análise que considere os impactos derivados destas mudanças [...] enquanto processo recente da organização capitalista, tendo em vista que é desde esta abordagem que se poderá avaliar mais objetivamente as formas de controle social nas organizações formais/estáveis e as de pertença, ou seja, [...] das interações que as organizações estabelecem com as transformações que se estão operando no Estado Capitalista Contemporâneo em termos de estratégias de poder, de definição de novos padrões de acumulação de capital e de desenvolvimento das relações sociais de produção, de maneira que se possa olhar para os temas recorrentes exaustivamente estudados de um outro prisma, o qual possa contemplar aspectos humanos, ideológicos e imaginários tanto quanto os econômicos, políticos e sociais (FARIA, 2002, p. 9).

Para retratar as tensões entre sindicato - Estado - mercado, o "esquema de um espaço integrado de debate de normas" pode ser usado da seguinte forma: 
Figura 2. O Espaço tripolar

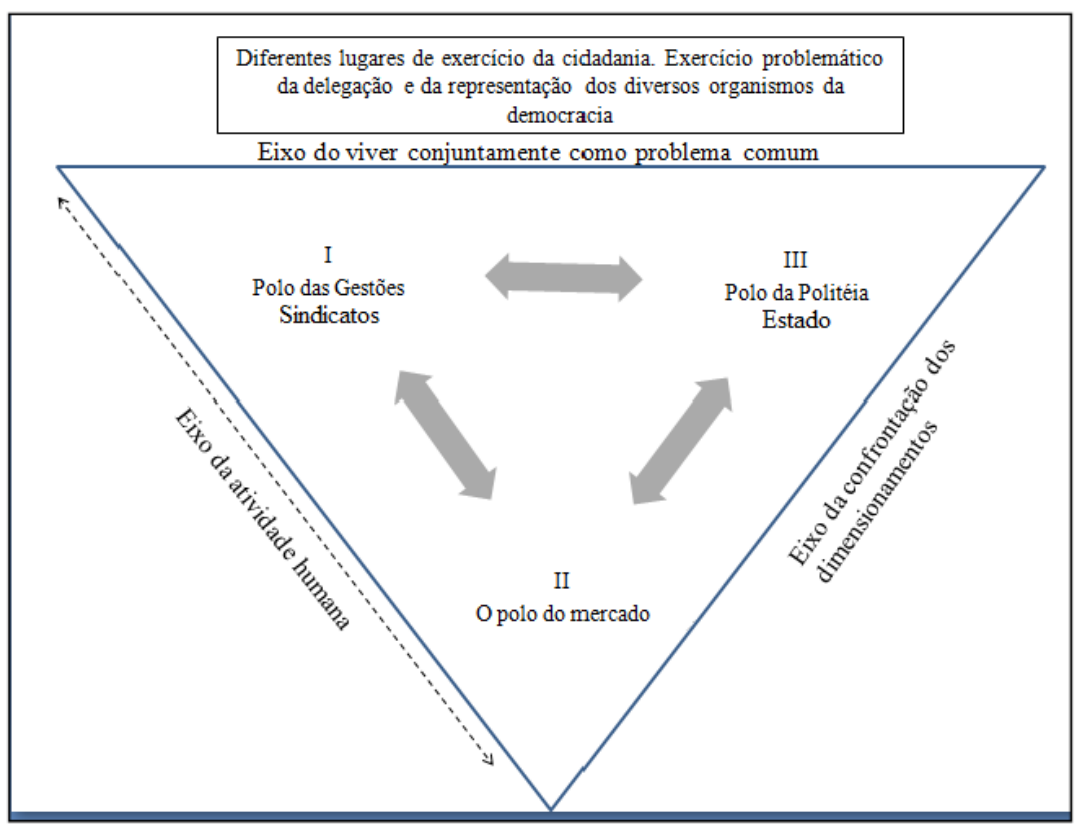

Fonte: Schwartz e Durrive (2015, p. 391).

No polo 1 (das Gestões), está o sindicato, o que faz usos de si em confrontação, antecipação e reação às tensões nos outros dois polos; no polo 2 (do Mercado), encontram-se os anseios do empresariado, a busca pelo lucro, a redução de custos, o livre mercado e a flexibilização das leis comerciais e trabalhistas; já no polo 3 (da Politéia), estão os valores que o Estado deveria salvaguardar, no caso, os direitos trabalhistas, a fiscalização e a promoção da saúde e bem estar no trabalho.

Assim que decidiu militar na causa sindical, Juvenal que antes apenas exercia sua profissão como vigilante, de repente se viu imerso em um amplo espaço de debate de normas (DURRIVE; SCHWARTZ, 2008), ele estava, mais precisamente, no primeiro polo, que é o polo em que a história é construída a cada dia, é também neste espaço que se faz emergir as reservas de alternativas, o fazer de outro modo, as renormalizações.

Para a análise dos tensionamentos entre os polos de acordo com os relatos de Juvenal, foram separados dois tópicos: I) O eixo sindicato - mercado; e II) O eixo sindicato - Estado.

\subsubsection{O eixo sindicato - mercado}

Em termos teóricos o eixo sindicato - mercado, ou seja, o neoliberalismo e o sindicalismo se opõem, no entanto em termos políticos há uma possibilidade de eles se 
convergirem, Antunes e Silva (2015, p. 525) explicam este fenômeno: “[...] as últimas décadas parecem empurrar o novo sindicalismo em direção a uma esdrúxula combinação, síntese de ao menos três movimentos: a velha prática peleguista, a forte herança estatista e a forte influência do ideário neoliberal". Foi neste cenário que Juvenal conheceu o seu sindicato dos vigilantes.

\begin{abstract}
"Aí conheci o sindicato dos vigilantes, não essa turma aqui que eu estou, a atual, mas uma anterior, para derrubar um cara que estava a mais tempo ainda, que era o [Nome], ele ficou praticamente mais de 10 anos, nós estamos em 2019, nós estamos lá há 2 anos, pegamos 5 de intervenção, 7 , mais 5 da outra, 12, foi logo que eu iniciei, há uns 15 anos atrás era o período dele. Aí a gente já via que o negócio não estava certo, entrou uma renovação no sindicato e eu me envolvi, nas assembleias, nas passeatas, sempre estava por perto, gostava sempre de estar acompanhando. [...] Eles estavam desviando dinheiro, negociando acordos com as empresas, uma negociata fajuta, nós confiamos na gestão e no final saímos prejudicados".
\end{abstract}

O sindicato neste momento claramente desdenhou de seu propósito como uma entidade que luta pelos direitos do trabalhador e foi atraído pelo polo do mercado, chegando até mesmo a ficar do lado das empresas infratoras nas negociações. Foi nesse momento que Juvenal usou o seu corpo-si como um elemento de transgressão, por si e pelos outros, pois houve uma razão, uma vontade, houve uma dramática, que, de acordo com seus valores, seria necessária sua intervenção (SCHWARTZ, 2010c; DURRIVE; SCHWARTZ, 2008).

Já como sindicalista este mesmo corpo-si é fundamental para os usos de si de Juvenal em sua rotina na atividade sindical e resistência contra as pressões do mercado. Em suas visitas diárias, por exemplo, ele precisa lidar com situações das mais diversas, até mesmo bastante delicadas, como foi o caso destacado nos relatos, onde o vigilante demandante exercia seu trabalho em um ambiente claustrofóbico e insalubre:

\footnotetext{
"Tipo, uma vez visitamos um posto que o cara tinha que subir uma escada que o vão era mínimo, o cara que calça $41 \ldots 42$, tinha que pisar de lado, porque onde ele ficava era o lugar de uma caixa d'água, então fizeram uma adaptação e fizeram uma guarita, aí o cara tinha que subir dessa maneira e ficar lá em cima, e o portão de lá parou de funcionar, então ele tinha que descer sempre pra abrir. Outra coisa, não tinha banheiro. O banheiro depois passou a ser um vaso do lado de uma mesa, então o cara tinha que fazer tudo ali, inclusive comer. Também não tinha ventilador, ar condicionado nem nada, o cara levava o ventilador dele de casa".
}

Durrive e Schwartz (2008, p. 25) dizem que as dramáticas "têm lugar quando ocorrem acontecimentos que quebram os ritmos das sequencias habituais, antecipáveis, da vida". Ou seja, há sempre tensão presente nessas situações enquanto matriz de variabilidade, de história, de escolhas, de possibilidades de tratar os acontecimentos. Nesta visita realizada por Juvenal, mesmo sendo apenas mais uma em sua agenda, nunca é apenas mais uma visita para o seu 
corpo-si (SCHWARTZ, 2010c). A necessidade de colocar em sinergia seus valores, de articular, de se sensibilizar, ter empatia, faz de cada dramática única, um novo capítulo na construção da história do ser social.

\subsubsection{O eixo sindicato - Estado}

No Brasil, a tensão entre os polos sindicato - Estado é histórico. Mesclando traços da velha e persistente herança sindical peleguista, os sindicatos no geral sempre conservaram um burocratismo institucionalizado e verticalizado. No governo Lula (PT), as centrais sindicais passaram a receber verbas estatais, e, ao final dos anos 2000, o governo, ampliando consideravelmente esse mecanismo de cooptação, aumentava a influência estatal sobre os sindicatos ao possibilitar que as centrais também passassem a receber o Imposto Sindical, criado na ditadura Vargas, ao final dos anos 1930 (ANTUNES; SILVA, 2015; DAL ROSSO, 2013).

O primeiro ano de Juvenal como sindicalista foi marcado por uma relação estreita, intensa e delicada com o Estado, na figura do poder judiciário. É que quando sua chapa assumiu a gestão do sindicato, o mesmo ainda estava sob intervenção judicial, foi o último ano de cinco no total. Nesse período todo o patrimônio do sindicato era gerido e controlado pelo interventor ou pela juíza. Cada operação financeira demandava o crivo judicial. "Nós passamos um ano pedindo benção pra juiz, contador, pra liberação de verba".

Pode-se observar que o sindicato sofreu forte prescrição das rotinas nesse ano. Como não houve período de transição entre diretorias, os novatos, Juvenal incluso, tiveram que aprender em partes pela justiça do trabalho, em partes sozinhos. Contudo Juvenal relata que apesar do clima organizacional tenso e da burocracia excessiva, a intervenção judicial no aspecto aprendizado foi positiva: "Pra nós não foi ruim não porque nós aprendemos a como administrar, como gerir um sindicato, como fazer as coisas certinhas, [...]”.

Vale destacar que o trabalho prescrito não se restringe apenas aos procedimentos predefinidos ou normas técnicas. Engloba também as condições dadas para a realização do trabalho (SCHWARTZ, 2010b), por exemplo: é trabalho prescrito o fato de Juvenal visitar os vigilantes demandantes usando o ônibus como meio de transporte, por longo período, levando em conta que os carros do sindicato foram confiscados.

Além de ter travado a batalha da intervenção judicial em âmbito estadual, Juvenal e seu sindicato lutam diariamente em âmbito federal, visto que a ideologia neoliberal cooptou grande 
parte das forças políticas do país. A resultante é um constante ataque por parte do Estado aos direitos trabalhistas e ao próprio sindicalismo (ANTUNES; SILVA, 2015). Juvenal reclama da crescente campanha de difamação que é empregada contra a classe sindical no Brasil por parte dos agentes públicos e políticos: "Eu quero o meu direito, quero o direito os dos outros, o de todo mundo. Mas muitos acham que eu só tô me beneficiando em cima, [...]. Se eu não grito, o cara não grita, como é que fica? Vai ficar no mesmo?".

Juvenal não só assume essa guerra como pessoal, mas também a encara na linha de frente, em um claro embate de valores com o meio no qual se vive. Este embate é histórico, e Juvenal continuamente faz história ao evocar suas dramáticas do uso do corpo-si nesta luta: "Eu participo, brigo, luto. Nós temos uma guerra grande. O governo tá aí, a insegurança, totalmente uma guerra entre os poderes. O presidente (atual) quer uma coisa...".

\section{CONSIDERAÇÕES FINAIS}

Esta pesquisa, com base na perspectiva ergológica, teve como objetivo compreender as experiências vividas pelo sindicalista entrevistado e os usos do corpo-si em sua atividade de trabalho. Para alcançar esse objetivo, primeiro buscou-se resgatar a história de vida do sindicalista através de seus relatos em entrevistas abertas e em profundidade, com o entrevistado à vontade para falar. Esse método de história oral de vida evita análises sempre "sobre" eles para uma análise "deles". Em síntese, este artigo ilumina, pela lente da Ergologia, os usos do corpo-si, por si e pelos outros, do sindicalista entrevistado no ínfimo de sua atividade rotineira no cargo de diretor jurídico do sindicato, a nível micro; e a nível macro o franco debate em um espaço integrado de normas e valores com as forças evanescentes do mercado, de um lado, e a mão pesada do Estado, de outro.

Até mesmo pela complexidade que o ser Juvenal mostrou nas narrativas, este trabalho encontrou um limite teórico para a análise de certas situações da vida do entrevistado. A démarche ergológica contém uma porção da psicodinâmica do trabalho nas vozes de Dejours (2012) e de Clot (2006), por exemplo; entretanto, passagens da vida de Juvenal, como a relação com a sua mãe, o preenchimento e a falta que ela fez, a relação com os irmãos ou ainda os conflitos com seu pai como a disputa da autoridade familiar, poderiam ser aproveitados para uma produção de dados com o enfoque psicanalítico de Freud (2006) nos conceitos de narcisismo, castração, identificação ou desejo pelo falo e de complexo de Édipo. Já as 
contribuições psicanalíticas de Lacan (1999) poderiam ajudar no entendimento sobre a origem da autoridade e do poder nas relações políticas e sociais de Juvenal, além de compreender esse poder na linguagem e nas trocas simbólicas. Ajudaria também a entender o processo de formação ideológica do sujeito, e a pensar, de forma ampla, em formas mais democráticas de relação ao poder e ao saber. A psicanálise então, aliada ao método de história oral de vida, pode ser lente teórica para pesquisas futuras sobre o trabalho. Já para o campo da Ergologia, este trabalho pode sugerir uma análise mapeada e cartografada dos usos do corpo-si e das renormalizações dos sindicalistas, podendo assim otimizar ações e processos de rotina do sindicato. Uma pesquisa cartográfica com base nos conceitos da Ergologia seria pertinente neste sentido.

Esta pesquisa surge também como um leque de oportunidades para pesquisas futuras no campo do Sindicalismo. As várias nuances da vida de Juvenal podem inspirar diversas áreas do conhecimento a pesquisarem de forma inédita a atividade sindical brasileira.

O artigo buscou contribuir, especialmente para os Estudos Organizacionais, como é possível repensar o trabalhador de uma forma mais reflexiva e humana a partir do conhecimento do uso do corpo-si de cada trabalhador, o reconhecimento de que este é um ser humano complexo e que por trás dele há uma infinidade de valores acumulados ao longo de sua história. Entende-se, no momento histórico em que se configura, que o administrador assuma protagonismo para a promoção de relações de trabalho mais justas, que contemplem a dignidade e a vida.

Desvelar os valores de Juvenal foi essencial para colocar em discussão fenômenos decorrentes da vida social, como neoliberalismo está espelhando os valores econômicos da mercadoria em detrimento dos valores humanos.

A história de Juvenal mostra que é preciso confiar na ação, mesmo ela aparentando estar em seu limite de possibilidades, porque é exatamente nesse espaço que pode estar a realização do que realmente se almeja. A maior lição que Juvenal deixa para esta pesquisa é que mesmo com as maiores perdas, nas sucessivas falhas, decepções, mesmo sem perspectiva, mesmo sendo reduzido à invisibilidade, mesmo a ponto de desistir da vida, o ser humano tem o poder da redenção, de escolher a si mesmo, achar um sentido em sua vida através do trabalho.

\section{REFERÊNCIAS}


ALBERTI, V. Manual de História Oral. 2. ed. Rio de Janeiro: Editora FGV, 2004. 236p.

ANTUNES, R. L. C. Adeus ao trabalho? ensaio sobre as metamorfoses e a centralidade do mundo do trabalho. 16. ed. São Paulo: Cortez, 2015.

ANTUNES, R. L. C. Os modos de ser da informalidade: rumo a uma nova era da precarização estrutural do trabalho? Serviço Social \& Sociedade, n. 107, p. 405-419, jul./set., 2011. Disponível em: http://www.scielo.br/pdf/sssoc/n107/02.pdf.

ANTUNES, R. L. C. Os sentidos do trabalho: ensaio sobre a afirmação e a negação do trabalho. 6. ed. São Paulo: Boitempo, 2002. 258p.

ANTUNES, R. L. C. Neoliberalismo, trabalho e sindicatos: reestruturação produtiva na Inglaterra e no Brasil. 2. ed. São Paulo: Boitempo, 1998. 131p.

ANTUNES, R. L. C.; SILVA, J. B. Para onde foram os sindicatos? Do sindicalismo de confronto ao sindicalismo negocial. Caderno CRH, v. 28, n. 75, p. 511-528, set./dez., 2015. Disponível em: http://www.scielo.br/pdf/ccrh/v28n75/0103-4979-ccrh-28-75-0511.pdf.

ARAÚJO, P. M.; BIANCO, M. F.; VALADÃO, K. T.; ANCHIETA, R. B. Estágio docente no curso de Administração: uma análise da atividade do discente-professor. Revista Principia. Divulgação científica e tecnológica do IFPB, n. 47, p. 24-36, 2019. Disponível em: https://periodicos.ifpb.edu.br/index.php/principia/article/view/2621/1160. Acesso em: 30 mar. 2020.

BARROS, V. A.; LOPES, F. T. Considerações sobre a pesquisa em história de vida. In: SOUZA, E. M. (Org.). Metodologias e analíticas qualitativas em pesquisa organizacional: uma abordagem teórico-conceitual. Vitória: EDUFES, 2014. Disponível em:

http://repositorio.ufes.br/bitstream/10/939/1/livro\%20edufes\%20Metodologias\%20e\%20anal \%C3\%ADticas\%20qualitativas\%20em\%20pesquisa\%20organizacional.pdf.

BARROS, V. A.; SILVA, L. R. A pesquisa em História de Vida. In: GOULART, I. (Org.). Psicologia organizacional e do trabalho: teoria, pesquisa e temas correlatos. São Paulo: Casa do Psicólogo, 2002. p. 133-146.

CANGUILHEM, G. O normal e o patológico. Trad. de Maria Tereza Redig de Carvalho Barrocas \& Luiz Octávio Ferreira Leite. 5. ed. Rio de Janeiro: Florence Universitária, 2000.

CAPELlE, M. C. A.; BORGES, C. L. P.; MIRANDA, A. R. A. Um exemplo do Uso da História Oral como técnica complementar de pesquisa em administração. In: Encontro de Estudos Organizacionais da ANPAD, VI, 2010, Florianópolis. Anais... Florianópolis: ANPAD, 2010. Disponível em: http://www.anpad.org.br/admin/pdf/eneo117.pdf.

CAVAIGNAC, M. D. Sindicalismo em tempos difíceis: reflexões sobre a organização política de uma classe trabalhadora cada vez mais fragmentada. Revista LABOR, v. 1, n. 8, p. 48-63, 2012. http://www.repositorio.ufc.br/bitstream/riufc/23368/1/2012_art_mdcavaignac.pdf. 
CHANLAT, J. F. O Desafio Social da Gestão: a contribuição das ciências sociais. In: BENDASSOLLI, P. F.; SOBOLL, L. A. P. (Orgs.) Clínicas do Trabalho: novas perspectivas para a compreensão do trabalho na atualidade. São Paulo: Atlas, 2011.

COLBARI, A. Rumos do movimento sindical no Espírito Santo. Vitória: Edufes, Florecultura, 2003.

CLOT, Y. A função psicológica do trabalho. Petrópolis: Vozes, 2006.

DAL ROSSO, S. Fragmentação sindical. Educ. rev., n. 48, p.3 9-52, 2013.

DEJOURS, C. Trabalho e Emancipação. Trad. Franck Soudant. Brasília: Paralelo 15, 2012. $222 p$.

DEJOURS, C. A loucura do trabalho: estudo de psicopatologia do trabalho. 2. ed. São Paulo: Cortez Obore, 1987.

DEJOURS, C.; ABDOUCHELI, E.; BETIOL, M. S.; JAYET, C. Psicodinâmica do trabalho: contribuições da Escola Dejouriana a análise da relação prazer, sofrimento e trabalho. São Paulo: Atlas, 1993.

DURAFFOURG, J.; DUC, M.; DURRIVE, L. O trabalho e o ponto de vista da atividade. In: SCHWARTZ, Y.; DURRIVE, L. (Org.). Trabalho \& Ergologia: conversas sobre a atividade humana. 2. ed. Niterói: EdUFF, 2010, p. 47-87.

DURRIVE, L. A atividade humana, simultaneamente intelectual e vital: esclarecimentos complementares de Pierre Pastré e Yves Schwartz. Trabalho, Educação e Saúde, v. 9, n. 1, p. 47-67, 2011. Disponível em: http://www.scielo.br/pdf/tes/v9s1/03.pdf.

DURRIVE, L.; SCHWARTZ, Y. Revisões temáticas: glossário da Ergologia. Laboreal, v. 4, n. 1, p. 23-28, 2008. Disponível em: http://laboreal.up.pt/files/articles/2008_07/pt/2328pt.pdf.

FREUD, S. (1923) A Organização Genital Infantil (Uma Interpolação na teoria da Sexualidade) In: Edição standard brasileira das obras psicológicas completas de Sigmund Freud. v. 19, Rio de Janeiro: Imago, 1996/2006.

FARIA, J. H.; Economia Política do Poder: uma proposta Teórico-Metodológica para o estudo e a Análise das Organizações In: ENCONTRO DE ESTUDOS

ORGANIZACIONAIS, 2., 2002, Recife. Anais... Recife: Observatório da Realidade Organizacional: PROPAD/UFPE: ANPAD, 2002. 1 CD. Disponível em: http://www.anpad.org.br/admin/pdf/eneo2002-21.pdf.

GASKELL, G. Entrevistas Individuais e Grupais. In: BAUER, M. W.; GASKELL, G. (Orgs.). Pesquisa qualitativa com texto, imagem e som: um manual prático. Petrópolis: Vozes, 2000. p. 64-89. 
GODOI, C. K.; MELLO, R. B.; SILVA, A. B. Pesquisa qualitativa em estudos

organizacionais: Paradigmas, estratégias e métodos. $2^{\circ}$ Ed. São Paulo: Saraiva, 2010.

GOMIDE, A. D.; NOGUEIRA, M. L. M.; BARROS, V. A. Histórias de vida e trabalho cultural: a construção do sujeito e a pertinência da memória. Cadernos Ceru, v. 21, n. 2, p. 139-151, dez., 2010. Disponível em: http://www.revistas.usp.br/ceru/article/view/11921/13698. Acesso em: 19 de jan. 2018.

HAZAN, B. F.; POLI, L. C. Os percalços do sindicalismo e sua ressignificação no Estado Democrático de Direito. Revista de Direitos Sociais, Seguridade e Previdência Social, v. 3, n. 1, p. 60-80, jan./jun., 2017. Disponível em:

https://www.indexlaw.org/index.php/revistadssps/article/view/1958/pdf.

HOLZ, E. B.; BIANCO, M. F. Ergologia: uma abordagem possível para os estudos organizacionais sobre trabalho. Cadernos EBAPE.BR, v. 12, Edição Especial, art. 6, p. 494512, ago., 2014. Disponível em: http://www.scielo.br/pdf/cebape/v12nspe/07.pdf.

LACAN, J. O Seminário, livro 5: as formações do inconsciente. Rio de Janeiro: Jorge Zahar Editor, 1999.

LÉVY, A. Ciências clínicas e organizações sociais. Belo Horizonte: Autêntica, 2001.

MARX, K. O Capital: crítica da economia política. Livro I: o processo de produção do capital. São Paulo: Boitempo, 2013.

MEIHY, J. C. S. B. Manual de História Oral. São Paulo: Edições Loyola, 4ª Ed., 2002.

ODDONE, I. Experiência. Revista Laboreal, v. 3, n. 1, p. 52-53, 2007. Disponível em: http://laboreal.up.pt/files/articles/2007_07/pt/52_53pt.pdf.

RODRIGUES, L. M. Destino do sindicalismo. São Paulo, Edusp, 2002. Disponível em: https://edisciplinas.usp.br/pluginfile.php/323770/mod resource/content/2/Rodrigues, \%20Le\% C3\%B4ncio\%20Martins, \%202009.\%20Destino\%20do\%20Sindicalismo.pdf.

SAFATLE, V. Uma certa latitude: Georges Canguilhem, biopolítica e vida como errância. Scientiæ Studia, São Paulo, v. 13, n. 2, p. 335-367, 2015. Disponível em: http://www.revistas.usp.br/ss/article/view/103333/101778. Acesso em: 12 fev. 2019.

SCHWARTZ, Y. Motivações do conceito de corpo-si: corpo-si, atividade, experiência. Letras de Hoje, v. 49, n. 3, p. 259-274, jul./set., 2014. Disponível em: http://revistaseletronicas.pucrs.br/ojs/index.php/fale/article/view/19102/12151. Acesso em: 13 mar. 2018.

SCHWARTZ, Y. Conceituando o trabalho, o visível e o invisível. Trabalho, Educação e Saúde, v. 9, n. 1, p. 19-45, 2011. Disponível em: http://www.scielo.br/pdf/tes/v9s1/02.pdf. 
SCHWARTZ, Y. Uso de si e competência. In SCHWARTZ, Y.; DURRIVE, L. (Org.)

Trabalho \& Ergologia: conversas sobre a atividade humana. Niterói: Editora da UFF, $2^{\text {a }}$ ed., 2010a.

SCHWARTZ, Y. Trabalho e Ergologia. In: SCHWARTZ, Y.; DURRIVE, L. (Org.).

Trabalho \& Ergologia: conversas sobre a atividade humana. 2. ed. Niterói: EdUFF, 2010 b. 131-148p.

SCHWARTZ, Y. Trabalho e uso de si. In: SCHWARTZ, Y.; DURRIVE, L. (Org.). Trabalho \& Ergologia: conversas sobre a atividade humana. 2. ed. Niterói: EdUFF, 2010c. 189-204p.

SCHWARTZ, Y. Reflexão em torno de um exemplo de trabalho operário. In: SCHWARTZ, Y.; DURRIVE, L. (Orgs.). Trabalho \& Ergologia: conversas sobre a atividade humana. 2. ed. Niterói: EdUFF, 2010d. p. 37-46.

SCHWARTZ, Y. Trabalho e Saber. In: Seminário Internacional Trabalho e Saber. Belo Horizonte, 12-16 mai, 2003, mimeo.

SCHWARTZ, Y.; DUC, M.; DURRIVE, L. A linguagem em trabalho. In: SCHWARTZ, Y.; DURRIVE, L. (Orgs.). Trabalho \& Ergologia: conversas sobre a atividade humana. 2. ed. Niterói: EdUFF, 2010. p. 25-36.

SILVA, M.; SALIBA, M. G. Globalização e Direito: Perda de Soberania do Estado e Reforma Constitucional na Periferia do Capitalismo. Revista Brasileira de Direito, v. 11, n. 2, p. 85-103, jul./dez., 2015. Disponível em: https://seer.imed.edu.br/index.php/revistadedireito/article/view/974/720. Acesso em: 04 abr. 2018.

SINGER, A. Os sentidos do lulismo. São Paulo: Companhia das Letras, 2012

TELLES, A. L.; ALVAREZ, D. Interfaces ergonomia-ergologia: uma discussão sobre trabalho prescrito e normas antecedentes. In: FIGUEIREDO, M. et al. (Orgs.). Labirintos do Trabalho: interrogações e olhares sobre o trabalho vivo. Rio de Janeiro: DP\&A, 2004.

TRINQUET, P. Trabalho e educação: o método ergológico. Revista HISTEDBR On-line, v. 10, n. 38e, p. 93-113, ago., 2010. Disponível em:

https://periodicos.sbu.unicamp.br/ojs/index.php/histedbr/article/view/8639753/7318. Acesso em: 03 abr. 2018.

TRÓPIA, P. V. Força Sindical: política e ideologia no sindicalismo brasileiro. São Paulo: Expressão Popular, 2009,

WISNER, A. A inteligência no trabalho: textos selecionados de ergonomia. São Paulo: Fundacentro, 1994. 